\title{
Gender Discrimination - Prevailing State In Pakistan
}

\author{
Sara Pervez \\ \& \\ Khalid M. Iraqi \\ Department of Public Administration \\ University of Karachi
}

\begin{abstract}
Gender inequality is defined as unequal or unjust treatment because of someone's gender. Generally, females are the victims of such discrimination.. Inequality in terms of gender represents a significant social problem in Pakistan as well as throughout the world. The fact that women receive fewer privileges in terms of economic benefits and education has become a worldwide issue. Even in Pakistan there is a huge gender gap in terms of allocation of economic benefits and education. Not only that, females encounter discrimination in all other areas of life and face violence which has been mentioned in the study. The case study of different women has been used for this study. A sample size of 15 respondents was taken. A structured questionnaire of 23 questions was prepared. It was found that in Pakistan, the violence against women takes place in many forms such as honour killings, acid attacks, early marriages, human trafficking, rapes, sexual harassment at workplace etc. In addition to that, the Islamic concept of gender equality has been explained in order to examine the Islamic practices that take place in Pakistan in terms of gender equality. The data has been collected through secondary sources as well as primary including the interviews of the victims of gender violence, various research journals, scholarly articles, research papers etc
\end{abstract}

Keywords: Gender Discrimination, Women, Violence, Education, Equality.
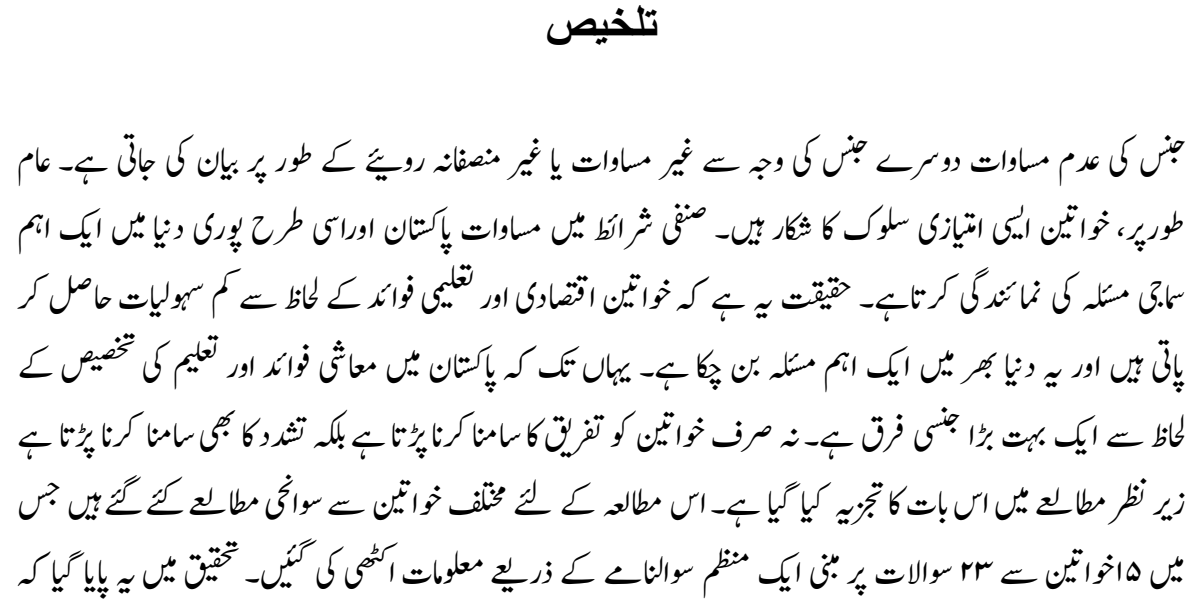


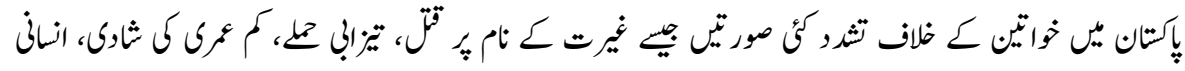

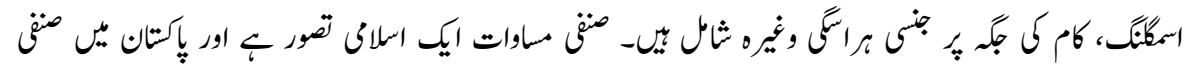

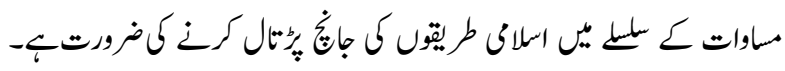

$$
\begin{aligned}
& \text { كليوىالفاط: جنى ثتيز، نواثين، تثرو، تعيم، مساوات- }
\end{aligned}
$$

\section{Introduction}

Gender refers to socially constructed roles and responsibilities of women and men of a society. The difference in roles and responsibilities among women and men stems from our families, societies and their culture. The concept of gender includes our expectations about the characteristics, attitudes and behaviors of women and men and is vital in facilitating gender analysis. The different roles, rights and resources that both the genders have in society are important determinants of the nature and scope of their inequality and poverty. Inequality in access to resources between women and men is most common in poor and developing countries. Gender inequality refers to inequality in conditions among women and men for realizing their full human rights and potentials.

Gender equality usually refers to a condition of parity between men and women. However, given the widespread tendency to ascribe different roles and status to each in various settings across societies, what should constitute gender equality has provoked fierce debate (Brownie, 2007). Based on the premise that females and males are inherently different in their reproductive, psycho, physiological, and consequently social functions, the question remains whether men and women can ever be truly "equal." Answers depend on the degree to which one thinks women's and men's capacities differ, what should be equalized, and by what means (Eagly, 2007).

Sexual discrimination involves treating someone differently, usually less favourably, because of his or her gender. The way it was in the past, men and women were treated very differently. Boys and girls were taught to follow particular roles in society based on stereotypical ideas about what they were considered capable of doing. Men and women were - and still are to an extent - expected to exhibit typically masculine or feminine behaviour. Such stereotyped views include seeing males as strong, aggressive, and tending to hide their emotions. Females, on the other hand, are seen as sensitive, over-emotional, and gentle .As a result of these views, women were often denied opportunities and experiences that men received as a matter of right (Helicon, 2016). 
There are different roles and responsibilities of women and men in every society. These different roles and responsibilities stem from our families, societies, countries and our culture. The concept of gender discrimination includes our expectations about the characteristics, attitudes and behaviours of women and men, how equally the resources are distributed among them and how freely they can exercise their fundamental rights which are vital in facilitating gender analysis. Inequality in terms of gender for access to resources is most common in third world. Gender inequality means inequality in conditions among women and men to enjoy full human rights.

Generally we talk about uplifting of women or empowerment of women in every society, but still gender discrimination is practiced everywhere. It is increasing day by day in every country or nation in one way or the other. The nature of inequalities based on gender may have been changed but the policies and programs have failed to reduce gender discrimination. Young girls and elderly women continue to strive for their basic fundamental rights even in the developed and under developed nations.

Besides coping up with this discriminatory attitude, women also face and are the victims of violence which takes many forms, mainly physical and mental i.e. physical violence in the form of domestic physical abuse where female is beaten up on frequent basis at home. This process of physical abuse is sometimes also carried by other women in laws who torture young or newlywed female physically for various purposes. This sometimes leads to serious incidents which may turn into the death of the victim. Other physical tortures that women face at the societal level include rapes, sexual harassment, honor killings, sex selective abortion etc.

The mental violence that females have to face includes again violence at domestic and societal level. We are naming it as "violence" here since it is a type of torture that deteriorate a girl's individuality overall. Mental violence includes the myths and stories that are fed into girls' minds since the beginning that they are inferior to men and hence they have no right to raise their voices against any unequal or unjust attitude prevailed against them. The newlywed girls often encounter such mental tortures at in laws home where they are supposed to live their lives as an inferior living beings with respect to her in laws, are abused and shouted over dowry or small negligible day to day issues and are usually not allowed to even reiterate against this prejudice. This cowardly act is equally carried by other women of the household along with the husband and other in law males. If however any girl finds the courage to raise her voice and refuse to tolerate such violence which sabotages her individuality, she is perceived as un loyal to her husband and morally degraded. Consequently, she is either asked to both surrender and continue to live the same way or otherwise take a divorce resulting in devastating and demolish her societal image. At the societal level, females encounter the issue of sexual harassment 
at workplace, deprived from the basic right of education, bread earning, less wages and they aren't even supposed to go outside freely and hangout.

In Pakistan, men and women are still conceptually separated or segregated into two different worlds (ADB, 2002). The male members of the family are allocated more household resources as a consequence and the education is prioritized for boys' vis-à-vis girls as boys are supposed to be the only bread winners of the family and the girls are required to oversee the domestic skills at home. The girl is considered to be the burden on the family and hence the birth of a girl is not welcomed by most of the families in Pakistan. The gender inequalities are observed in infancy stage, education sector, employment, household decision making, and wage labor markets. Due to this discrimination, a Pakistani woman also faces violence at domestic and societal level in the form of insurgency.

\section{Objective of the Study}

1. To analyze the gender discrimination in Pakistan keeping in view the Islamic perspective of equality.

2. To analyze gender discrimination at each stage of life in Pakistan.

3. To examine the forms of gender discrimination prevailing in Pakistan.

\section{Methodology}

It is a qualitative research. Both primary and secondary sources have been used. The secondary sources used are research articles, papers, journals and books. The primary sources used are interviews with various women usually from less privileged background who have experienced sexual disparity or violence. A total of 15 women were interviewed who shared their experiences based on the questions asked. The questions covered the following areas: inequality at infancy, childhood and adolescent, socioeconomic practices, honor killing, sexual harassment and lesser wages. The responses were recorded and have been discussed. International reports on gender discrimination and women violence including reports by UNESCO, World Bank, UNICEF, Amnesty International, Quranic verses related to gender equity etc have been cited.

\section{Literature Review}

There is a wide research on gender inequality. Few papers have been highlighted as under: Chaudhry and Rahman conducted a research in 2009 on female literacy rate in Pakistan. According to them, the female literacy rate in Pakistan was upto $38 \%$ in 2006-07 (Chaudhry, 2009). The increase in female education can improve human development outcomes such as child survival, health and schooling (World Bank 2001, Schultz 2002, Strauss and Thomas 1995, King and Hill 1993, World Bank 2007). 
Maliha Tarar and Venkat Pulla (2014) studied on patriarchy and gender based violence amongst Pakistani women. They conducted empirical study of fifty two women living in seven women's shelters of the Punjab, Pakistan. The paper examines how poverty contributes to violent gender-power relations in Pakistani society and how patriarchal structure utilizes violence as a tool to control women and their sexuality, particularly in low income families. It also exposes women's resistance, resilience and coping strategies against poverty and violence. Their research findings exposed that there is a strong relationship between patriarchy, poverty and gender violence(Tarar \& Pulla, 2014).

Afzal et.al (2013) examined gender disparity at middle and secondary level education in Punjab using primary data from MICS 2007-08. They concluded that the gap due to differential treatment of parents with boys and girls under normal routine and social aspiration reflected the preference for males over females, specifically in rural areas. In urban areas, the importance of education proved dominating factor for eliminating distinction between male and female enrolment (Afzal M., 2013).

Sadruddin (2013) presented a paper on sexual harassment at workplace in Pakistan. The paper assesses the implementation of women rights in Pakistan and challenges confronted by women besides evaluating their contribution in raising their voice against harassment through the lens of working women. The phenomenological method was used for this study. The results revealed that harassment is routinely practiced at workplace in Pakistan and has genuinely impacted the working women to carryout work effectively.

Dipboye and Colella (2005) studied sexual discrimination in detail. Discrimination is alluded to those negative and low activities that confine the equivalent treatment of people. Generally, discrimination is seen as (1) the process of separation among persons to achieve a choice, considering real criteria, for example, legitimacy or potential, or (2) the method of separation among persons in light of attributes that are not sufficient or significant for the action for which the separation is made. They are of the view that Gender discrimination includes the second definition and presupposes unequal treatment, in view of subjective criteria (gender), in each stroll of life. Gender discrimination can take subtler and casual structures, for example, social prohibition, confinement and the evasion of interpersonal contact. Discrimination ascends to preferences (negative conduct towards somebody) and generalizations or stereotypes (qualities connected with somebody taking into account intellectual judgment) (Dipboye \& Collela, 2005).

Arif et al. (1999) conducted a research on the impact of poverty on primary school enrolment in Pakistan and also analyzed the gender gap in enrolment at primary level. They found that primary education is crucial for a society and plays an important role in economic growth and development of a country. The authors examined the effect of poverty on primary school enrolment. They concluded that there is equal effect of poverty on male and female 
enrolment and unequal effect on income. The boy's enrolment in school was not influenced by income while girl's enrolment was highly influenced by financial resources. They also found out that poverty plays major role in primary enrolment of girls and it has negative effect on primary school enrolment of girls in rural areas (Arif G.M., 1999).

Stromquist (2001) discussed in his research the poverty and its implications for education in Latin America. The study analyzes the aspects of national and international policy making regarding gender educational disparities in Latin America. Author said that the policies of South America regarding poverty alleviation are fair and equality based but gender disparities still exist in female access to education (Stromquist, 2001).

Knowles et al (2002) conducted a research on female education. They found that in developing countries, female education increases awareness regarding child birth and reduces infertility, infant mortality and increases school enrolment. The low investment in women's human capital is compounded by negative social and cultural practices that restrict women to get education and hence they have limited opportunities available to them in wage labor market. This has become the basis of social and economic dependency of women on men (Knowles, Lorgelly, \& Owen, 2002).

Ilkkaracan and Jamal in 2004 discussed in their study that patriarchy controls women's sexuality in most societies. They conducted their research on many Muslim women writers according to them the control on women is achieved through social, political, economic and cultural practices. Ilkkaracan also highlighted that religion often is misused as powerful instrument of control especially on women which is a legitimate violation of human rights (Ilkkaracan \& Jamal, 2004).

Babar (2007) explained in his study that lack of education and economic opportunities for women restrict their potential and thinking ability about their due rights. Furthermore, poverty and religious extremism are also barriers in the way of Pakistani women becoming progressive and independent. Women's actions are highly regulated by their male relatives. Men normally control their movements and behavior whether they happen to be the father, husband or brother. The women of Pakistan have fewer economic opportunities and they face major challenges to get their basic human rights including education. Babar also explained that unless the traditional thoughts regarding women as inferior, or as personal property are changed, it might be difficult for women to get any sort of freedom in this atmosphere of fear (Babar, 2007).

Samina and Manzoor (2012) studied patriarchy and women in Pakistan. The study analyses that most Pakistani women face inequality within the household and society. In South Asian societies, particularly in Pakistan, there are different methods applied including patriarchy to control women's social and economic behavior. They studied 
various household models and related them to a Pakistani household setup. They concluded that that the subordination and exclusion of Pakistani women in the development activities, flows from the barrel of patriarchy, which has denied women the right of choice in engaging themselves either in productive and reproductive activities. Under the patriarchal ideology, women's labor has been divided into productive and reproductive spheres (Isran \& Isran, 2012).

\section{Foundation of Equality in Islam}

Islam is the only religion on this planet which emphasized most on equality in all aspects. The foundation of Islam is based on the principle of equality regardless of age, gender, race, cast, social status etc. Since Pakistan was formed in the name of Islam, it is crucial to pinpoint various commandments given by Allah in His Holy book regarding equity, biasness or gender discrimination. Few of the verses have been quoted below:

1. "Oh mankind, fear your Lord, who created you from one soul and created from it its mate and dispersed from both of them many men and women... ". (Quran, 4:1, 7:189, 42:11, 16:72, 32:9, and 15:29).

2. "God has invested both genders with inherent dignity and has made men and women, collectively; the trustees of God on earth". (Quran 17:70 and 2:30).

3. "And their Lord responded to them (saying): Never will I allow to be lost the work of (any) worker among you, whether male or female; you are of one another... "(Quran, 3:195, 74:38, 16:97, 4:124, 33:35, and 57:12).

4. "The sole basis for superiority of any person over another is piety and righteousness not gender, color, or nationality" (Quran 49:13).

5. "I shall not lose sight of the labor of any of you who labors in My way, be it man or woman; each of you is equal to the other" (3:195).

The idea of gender parity is best exemplified in the Quranic interpretation of Adam and Eve. The Quran expresses that both genders were purposeful and free. Indeed, even in the issue of which sex was made first is not determined, inferring that for our objective in this world, it may not make any difference. As Allah puts in:

"O mankind! Be conscious of your Sustainer, who has created you out of one living entity (Nafs), and out of it created its mate, and out of the two spread abroad a multitude of men and women. And remain conscious of God, in whose name you demand your rights from one another, and of these ties of kinship. Verily, God is ever watchful over you! (4:1)".

Women are autonomous living beings, as exemplified by the way that every person will be responsible for their own particular deeds on the Day of Judgment:

"No human being shall be of the least avail to another human being" (82:19). 
If men were accountable of their women (fathers for their little girls, spouses for their wives, and so on.), then this responsibility would be exclusively on men's shoulders to hold up under until the Day of Judgment.

"And whatever wrongs any human being commits rests upon him alone; and no bearer of burdens shall be made to bear another's burden..." (6:165).

In Quran, reference to males and females is through characteristics and deeds, by which we will be judged. The most devout of us, or the individuals who take after God's orders, are alluded to as "devotees" or "mu'mineen". In numerous references, truth be told, the Quran reverberates this balance by expressively rehashing "men and women" with moral and useful qualities all through the verses, and even stresses this ten times in the accompanying verse:

"Verily for all men and women who have surrendered themselves unto God, and all believing men and believing women, and all truly devout men and truly devout women, and all men and women who are true to their word, and all men and women who are patient in adversity, and all men and women who humble themselves before God, and all men and women who give in charity, and all self-denying men and self-denying women, and all men and women who are mindful of their chastity, and all men and women who remember God unceasingly: for all of them has God readied forgiveness of sins and a mighty reward" (33:35).

It is easy to comprehend that Quran forces being a "mu'min" (devout) with genuine practice, so it is insufficient to simply have confidence on a fundamental level; we should put our belief into practice. The same applies to our faith in the balance of men and women; gender equality as laid out in the Quran should likewise be put into practice.

\section{Rights Given to Women by Islam}

Islam gave women the privilege to have individual property and allows a share in father's and spouse's property which is never given before Islam and after it, the privilege of free proprietorship and ownership.

Ladies has a privilege to hold and go about as full proprietor of property, she has right to offer and buy, contract and exchange or rent any or the greater part of their properties at her own wish.

By religious guidelines Muslim ladies may even keep their original surnames after marriage, which is an image of their free property rights as lawful substances as Islamic sharia permits. 
Moreover, she gets upkeep or rehabilitation of period after separation or passing of spouse called "iddat". She gets support for youngster bearing additionally living with spouse even if there should be an occurrence of separation.

\section{As Allah said in Quran: \\ "For men is a share of what the parents and close relatives leave, and for women is a share of what the parents and close relatives leave, be it little or much, an obligatory share" (Quran, 4:7).}

As per Islam the foremost obligation of a woman is conceiving an offspring and preparing him as a person who lives as indicated by Law of Creator. This is such a noble duty, to the point that can make a model adjusted society. After this duty notwithstanding, getting business is not taboo for women, but rather not on the expense of her youngsters and other family obligations. A few positions and administrations are fit for her tendency as nursing, instructing, drug, and social and beneficent work. A woman can do job if there is a financial need and on the off chance that she has capacity and time after her essential obligations.

\section{Equality in Practice}

Although Pakistan is an Islamic state and claims to follow Islamic laws and practices, it fails to promote the basic principle of equality. Pakistani woman is still struggling to get her basic fundamental rights of which she is deprived of.

In a Pakistani society, men and women are conceptually separated or segregated into two different worlds. The male members of the family are allocated more household resources as a consequence and the education is prioritized for boys as boys are supposed to be the only bread winners of the family and the girls are required to oversee the domestic skills at home. Hence education is not perceived as important for girls as it is for boys. As a result, girls are left with no other choice than to stay back at home, uneducated.

Due to the above mentioned scenario of a Pakistani rural sector, an incessant absence from schools among girls is more serious in provincial zones of Pakistan than in the urban regions. The illiterate mindset of the society has failed to realize the significance of women's education that could lead to the development of a nation (UNESCO, 2010).

The gender disparities are not only observed in the access to basic or higher education but also there is a lack of attention to gender equality in teaching management or academics that sees more women in early childhood education and primary teaching positions and more men in tertiary or higher teaching positions. The male dominant leadership roles 
have been observed in nearly most of the education institutes particularly in public sector which has become a common dilemma of our society. The leadership roles particularly in academics are reserved for men and they outnumber women in most of the higher academic positions. There are fewer opportunities for females to participate in training and continuing their professional development activities than their male counterparts. The female/male ratios in decision making process in educational sector particularly, are highly skewed against females and they experience unfavorable enrollment ratios in secondary and higher education (Crenshaw, 1989). Although the government claims to promote gender equality and cites the notions like "equal employment opportunities" the reality seems to be different.

This is prohibition or limitation made on the premise of sex which has the impact of invalidating the acknowledgment, delight or practice by women, regardless of their conjugal status on a premise of equality of men and women of human rights and essential opportunity in the monetary, social, common, political or other field (Chae et. al, 2008).

By the above explanation, it is clearly understood that the social and cultural rituals practiced in Pakistan in the name of Islam and which restrict women to get education, employment and deprive them of their basic human rights are totally against Islamic teachings and Islam does not allow men to discriminate against women in all forms.

The interviews were conducted on 15 women. The questions were divided into following six areas:

\section{Inequality at Infancy Stage}

The majority of respondents indicated that they faced discrimination when they were pregnant in various ways. They said that almost every member of the family sadly, the wise old ladies too want to have a son who would take their family's name forward and bring fortune to the family. They pray and carry out different rituals, often un Islamic, so that God may bless them with a boy. This mindset has been observed in most of the families of Pakistani society and the birth of a baby girl is not so warmly welcomed.

On the question regarding sex selective abortion, they responded that they did not have ultrasound facilities so majority did not get a chance to know the sex of the fetus. This also indicated that health facilities are deficient to rural women.

Sex-selective abortion is commonly practiced in many parts of the world where the pregnancy is terminated or aborted based on predicted gender of the fetus. The selective abortion of female fetuses is most common in areas where cultural norms value male children over female children, especially in parts of People's Republic of 
China, India, Pakistan, the Caucasus, and Southeast Europe (Goodkind, 1999)(A. Gettis, 2004) (Guilmoto, 2012).

The UNICEF report (2007) highlights the discrimination against females at various stages of life including infant stage when misuse of pregnancy diagnostic tools become common in the societies where there is a cultural and economic preference for males. It is important to note that these discriminatory attitudes against females are greatly observed in the third world countries where there is low literacy rates, poverty and patriarchy embedded in the society. Girls are deprived of their basic educational rights in these countries especially in Pakistan, India, Bangladesh, Kenya, Nigeria, Rwanda etc. (UNICEF, 2007).

\section{Inequality at Childhood and Adolescent}

When a girl enters her toddler or early childhood stage, she is deprived of her basic right of social needs especially in rural sector main reason reportedly being poverty and patriarchy. The social preference is given to sons since the birth of a girl was not welcomed earlier as well. The boys are given good and healthy diet since they are considered to be the bread winners of the family so their diet and health should be properly taken care of.

The respondents agreed to the point that they faced criticism and hurdles regarding access to education. Majority of the respondents were primary passed and were not allowed to study further. Besides education, they also experienced biasness in their day to day meals, where the male members are given good quality and quantity of food as compared to them.

It was found that they are bonded in early age marriages usually in their teens and many have little share in the economic activity of the family.

At adolescence, girls are not allowed to go to school because of the illiterate and negative cultural practices usually derived from ancient Hindu mythology and is still deeply rooted and embedded in our rural sector.

Among the serious threats to adolescence are abuse and savagery, and the absence of crucial knowledge or education about sexual and reproductive wellbeing, including HIV/AIDS. Particular zones that UNICEF (2007) highlighted were female genital mutilation/cutting; tyke or child marriage and untimely parenthood; sexual misuse, exploitation and trafficking; sexual and conceptive health; and HIV/AIDS. There is a lack of proper healthcare facilities for mothers and their newborns. It is assessed that every year more than half a million women - approximately one woman per minute - pass on 
as a result of pregnancy complications and labor, 99\% of which happen in third world nations (UNICEF, 2007). There is a need to highlight women's issues at the national level such as more and updated knowledge and access to better health care, family planning and education for women. The positive consequences of these productive measures get passed to the children and eventually to the whole society.

\section{Socio Economic Practices}

The biased socio economic practices that respondents indicated were early marriages, having little or no participation in decision making, the finances of the household are mostly governed by the male member. They shared their stories about how often they are beaten up by their spouses, brothers or fathers. Moreover, these women also indicated that they are abused verbally on almost daily basis. On a question regarding dowry, the married women among the respondents (10 out of 15$)$ replied that their in laws asked for a heavy dowry and upon not making it to the mark, they faced huge disputes or beaten up badly. Majority of the rural women are bonded in a marriage system called "watta/satta" in which the bride's brother is married to her sister in law. It was revealed that this system causes huge problems and disputes among the two families and majority of the cases often end up with divorce.

In Pakistani society, women are abused both emotionally and physically. When she is in her parents' home she will undoubtedly acknowledge whatever is given to her by her family, truth be told it is thought to be her obligation to acknowledge her family's commands regardless of the fact that they are outlandish and uncalled for. She moves under supervision of her new guardian when she gets wed and his orders get to be script of her life without having a privilege of raising her voice or expressing her consent since her advice or opinions are not viewed as sufficiently commendable to tune in.

Women in rural regions face more social and conventional imperatives and are relied upon to stay at home for the consideration of family. They have less access to livelihood and education than women from urban zones (Maliha and Venkut, 2014). Kumar and Varghese (2005) concede that women are living in men ruled society and have fewer chances to get training and job (Kumar, 2005). Government of Pakistan (2012) reported that rural women are denied of their fundamental needs particularly of medicinal needs and access to education is basically non-existent for them.

\section{Honor Killing}

When asked the question regarding honor killing, none of the respondents experienced such act by themselves however they shared the stories of honor killings in their villages which they had witnessed. According to them, the act of honor killings as a colossal 
negative effect on Pakistani women keeps on being boundless. These include a female being killed or murdered by a male relative, typically father, sibling or spouse, trying to ensure the family's honor. This is generally on the grounds that the woman is associated or charged with having an additional conjugal relationship or, if unmarried, of being enamored with a boy of whom the young girl's folks and relatives oppose. Several such killings occur in Pakistan consistently. This practice permits a male to murder a relative who is involved in un-islamic acts so as to hold the family's honor (Fisk, 2010). The killing is seen as an approach to reestablish the reputation and honor of the family (Matthew A. Goldstein, 2002).

In Pakistan, honor killings are referred to locally as karo-kari. Karo-kari is a compound word actually significance dark male (Karo) and dark female (Kari). Initially, Karo and Kari were allegorical terms for miscreant and adulteress, yet it has come to be utilized with respect to different types of perceived unethical conduct. Once a woman is named as a Kari, relatives view themselves as justified to slaughter her and the co-blamed Karo keeping in mind the end goal to reestablish family honor. In the larger part of cases, the casualty of the assaults is female with her assailants being male individuals from her family or group (Khan, 1999). Pakistan's Human Rights Commission reported that in 2010 there were 791 honor killings in the nation (Karimjee, 2011). Amnesity International refered to 960 episodes of women alone who were killed in honor killings that year (Amnesity International, 1999).

\section{Sexual Harassment at Workplace}

The respondents were asked if they had experienced sexual harassment at work ever. Out of the total 15, 13 women affirmed that they had been the victims of such harassment. Harassment is usually carried out by their superiors or bosses where they work. They even offer financial gains such as money, promotions or other tangible incentives like mobile phones, cars etc. in case the victim accepts to maintain the physical relationship with them. When the victim declined the offer, they were fired, asked to resign or demoted in the organization.

Provocation is one of the genuine nonsensical and inexcusable behaviors which routinely takes place at numerous working environments. In spite of the fact that this noteworthy truth is biting to be retained, yet it is the impression of the present condition of working women on the planet (Sadruddin, 2013). United Nations characterizes harassment as a sort of conduct (verbal or physical) that upsets work or advance hostile workplace. A standout amongst the most widely recognized sorts of badgering or harassment is lewd behavior or sexual harassment which is characterized as an exploitative set of accepted rules which a woman discovers debilitating or hostile (Goonesekere, 2004). This undesirable sex-related conduct (Fitzgerald, 1997) and covering marvels is the an integral 
part of all occupations and commercial ventures (Hunt, 2007). It could be as sex provocation (e.g., verbal/nonverbal behavior abuse); or immoral way of seeking attention (e.g., touching, calling); or sexual intimidation (e.g., sexual rewards or dangers) (Fitzgerald, Gelfand, \& Drasgow, 1995). (Fitzgerald L. G., 1995).

Harassment is routinely drilled at working environment in Pakistan and has truly affected the working women to do their work adequately. Inappropriate behavior for the most part happens in private division than in broad daylight foundations (Sadruddin, 2013).

\section{Women Work More Than Men But Are Paid Less}

Majority of the respondents agreed that their salaries are lesser as compared to their male counter parts. They work more but are under paid. Examples of such biasness were observed among household maids, maids who work in schools and the male peons. They said that they are made to work continuously throughout the day which also involves hard work such as carrying weight (school bags, chairs, tables) from one place to another, washing whole school and bathrooms etc. Whereas the office boy or peons in their schools do not have such job responsibilities instead they only carry office orders from one place to another, work as messengers and dispatching letters etc. which is comparatively less hard working and they are paid much higher than these maids.

In many countries of the world, especially in Pakistan, women are considered to be the inferior species of human being. They work side by side with men though but are generally paid lesser than men. They do $66 \%$ of the world's work, get 10 percent of the world's salary and own 1 percent of the method for production (Robbins, 1999).

As indicated by Inter Press Service, "On a worldwide scale, women develop more than half of all the sustenance that is developed. In sub-Saharan Africa and the Caribbean, they create up to 80 percent of fundamental foodstuffs. In Asia, essentially India, Pakistan, Bangladesh, China, they represent around 50 percent of food generation. In Latin America, they are primarily occupied with subsistence cultivating, agriculture, poultry and raising little domesticated animals" (Osava, 2010).

However women regularly get little acknowledgment for that. Indeed, numerous go unpaid. It is extremely troublesome for these women to get the money required to purchase hardware and so on, because many nations still don't acknowledge, or understand, that there is a change in the "conventional" roles of men and women (Shah, 2010).

Purposes behind such dissimilarity incorporate the way that women mostly are less paid on the grounds that they frequently perform low-status occupations, contrasted with men (UNICEF 2007, p.39). 


\section{Conclusions}

Gender roles consist of shared expectations that apply to individuals on the basis of their socially identified sex. It was found in this study that in Pakistani society, women are abused both emotionally and physically. When she is in her parents' home she will undoubtedly acknowledge whatever is given to her by her family, truth be told it is thought to be her obligation to acknowledge her family's commands regardless of the fact that they are outlandish and uncalled for. She moves under supervision of her new guardian when she gets wed and his orders get to be script of her life without having a privilege of raising her voice or expressing her consent since her advice or opinions are not viewed as sufficiently commendable to tune in. In Pakistan, woman is denied of her basic fundamental rights mainly education. Besides, they are supposed to stay indoors and are forced to look after household chores whereas males are the sole bread earners of the family. This system prevails in most of the households especially in rural sector and urban slums. The research findings indicate that despite of claiming itself the Islamic state, Pakistan has miserably failed to implement the basic Islamic principle of gender equality. Women are allocated lesser or no household resources and have very little or no share in property due to the illiterate patriarchal mindset. Poverty is also a big factor in promoting gender inequality which restricts children to get educated and consequently the illiterate practices prevail in the society. By the above findings, it is clearly understood that the social and cultural rituals practiced in Pakistan in the name of Islam and which restrict women to get education, employment and deprive them of their basic human rights, are totally against Islamic teachings and Islam does not allow men to discriminate against women in all forms

\section{References}

Afzal M., B. A. (2013, January). Gender Disparity in Pakistan: A Case of Middle and Secondary Education in Punjab. Journal of Research and Reflections in Education, vol.7:3, pp.113-124.

Amnesity International. (1999). Amnesity International Report 1999. New York: Amnesity International.

Arif G.M., S. N. (1999). Poverty, Gender, and Primary School Enrolment in Pakistan. The Pakistan Development Review, pp.979-992.

Asian Development Bank. (2002). ADB-NGO Cooperation Annual Report of Activities. Mandaluyong City: ADB. 
Babar, Z. U. (2007). Violence Against Women in Pakistan: Current Realities and Strategies for Change. Austria: European University Center for Peace Studies.

Browne, J. (2007). Gender Equality. In M. Bevir, Encyclopedia of Governance. Thousand Oaks, CA: Sage Publications. Retrieved from: https://search.credoreference.com/ content/entry/sagegov/gender_equality/0

Chae, D.H., Takeuchi, D.T., Barbeau, E.M., Bennett, G.G., Lindsey, J., Krieger, N. (2008). Unfair Treatment, Racial/Ethnic Discrimination, Ethnic Identification, and Smoking among Asian Americans in the National Latino and Asian American Study. American Journal of Public Health, vol.98, pp.485-492.

Chaudhry, I. a. (2009). The Impact of Gender Inequality in Education on Rural Poverty in Pakistan. European Journal of Economics, Finance and Administrative Sciences, pp.174-188.

Crenshaw, K. (1989). Demarginalizing the Intersection of Race and Sex: A Black Feminist Critique of Antidiscrimination Doctrine, Feminist Theory and Antiracist Politics. University of Chicago Legal Forum, pp.139-167.

Eagly. (2009). Gender Roles. In J. M. Levine, \& M. A. Hogg (Eds.), Encyclopedia of Group Processes and Intergroup Relations. Thousand Oaks, CA: Sage Publications, retrieved from: https://search.credoreference.com/content/entry/ sagegpir/gender_roles/0

Fisk, R. (2010, September 7). 'Honor' Killing: The Crimewave that Shames the World. Retrieved May 1, 2015, from Common Dreams: http://www.commondreams.org/news/2010/09/07/honor-killing-crimewaveshames-world

Fitzgerald, L. G. (1995). Measuring Sexual Harassment: Theoretical and Psychometric Advances. Basic and Applied Social Psychology, pp.425-445.

Goodkind, D. (1999). Should Prenatal Sex Selection be Restricted?: Ethical Questions and Their Implications for Research and Policy. Population Studies, 53(1), 49-61.

Goonesekere, S. (2004). Violence, Law and Women's Rights in South Asia. SAGE, pp.175-176.

Government of Pakistan. (2012, June 5). The Gazette of Pakistan. National Commission for Human Rights Act. Islamabad, Punjab, Pakistan: Government of Pakistan. 
Guilmoto, C. Z. (2012). HIGH SEX RATIO AT BIRTH IN SOUTHEAST EUROPE. Paris: Université Paris-Descartes.

Ilkkaracan, P. \& Jamal, A. (2004, January 1). Women and Sexuality in Muslim Societies. Resources for Feminist Research, p. 1.

Isran, S. \& Isran, M. A. (2012). Patriarchy and Women in Pakistan: A Critical Analysis. Interdisciplinary Journal of Contemporary Research in Business, vol.4:6, pp.835-859.

Knowles, S., Lorgelly, P. K. \& Owen, P. D. (2002). Are Educational Gender Gaps a Brake On Economic Development? Some Cross Country Imperical Evidence. Oxford Economic Papers, pp.118-149.

Karimjee, M. (2011, December 20). Pakistan:675 Women Killed. Retrieved from The Global Post: http://www.globalpost.com/dispatch/news/regions/asia-pacific/ pakistan/111220/pakistan-675-women-killed-honor-killings-2011.

Khan, A. (1999). Mobility of Women and Access to Health and Family Planning Services in Pakistan. Reproductive Health Matters, pp.39-48.

Kumar, H. \&. (2005). Women's Empowerment Issues and Strategies. New Delhi: Regency Publications.

Matthew A. Goldstein, J. M. (2002, September). Politics and the Life Sciences, vol.21:2, pp.28-37.

Osava, M. (2010, March 1). RIGHTS: Women More Educated, Not More Equal. Retrieved May 5, 2015, from Inter Press Service: http://www.ipsnews.net/2010/ 03/rights-women-more-educated-not-more-equal/

Robbins, R. H. (1999). Global Problems and the Culture of Capitalism. In A. \&. Bacon.

Sadruddin, M. M. (2013, January). Sexual Harassment at Workplace in Pakistan- Issues and Remedies about the Global Issue at Managerial Sector. Journal of Managerial Sciences, vol.7:1, p.113.

Sexual discrimination. (2016). In Helicon (Ed.), The Hutchinson Unabridged Encyclopedia with Atlas and Weather Guide. Abington, UK: Helicon. Retrieved from: https://search.credoreference.com/content/entry/heliconhe/sexual_discrimination/0 
Shah, A. (2010, March 14). Global Issues. Retrieved April 30, 2015, from Women's Rights: http://www.globalissues.org/article/166/womens-rights

Stromquist, N. (2001). What poverty Does to Girls' Education: the intersection of class,gender and policy in Latin America. Compare, vol.31:1.

Tarar, M. G., \& Pulla, V. (2014). Patriarchy, Gender Violence and Poverty amongst Pakistani Women: A Social Work Inquiry. International Journal of Social Work and Human Services Practice, pp.56-63.

UNESCO. (2010). Reaching the Marginalized. Paris: UNESCO Publishing.

UNICEF. (2007). The State of the World's Children 2007 Women and Children: The Double Dividend of Gendre Equality. New York: UNICEF.

Sara Pervez is Ph.D Scholar in the Department of Public Administration, University of Karachi.

Prof. Dr. Khalid M. Iraqi is Chairman in the Department of Public Administration, University of Karachi. 